\title{
I am also a We: Archiving the Women's Silence in Partition and Holocaust Narratives
}

\author{
Saumyata Joshi
}

Department of English and Cultural Studies, Panjab University, Chandigarh, India

\begin{abstract}
This paper seeks to analyse the women narratives which reside in the shadows of Partition of India (1947) and Holocaust of World War II (1941-1945) which find no acknowledgement within historical folds of the respective events. Doing so raises a pertinent question, as to why women irrespective of their status of being a first world woman or a third world woman share a same fate during moments of crises and even otherwise. There is a widespread criticism that a gendered reading of Partition and Holocaust often deviates one from understanding the history and actuality of the political causes behind such occurrences. But discussing the experiences and memories of women who endured rape, violation, and sexual abuse during these massacres does not belittle the collective suffering borne by Sikh, Hindu, Muslim and Jewish population. Rather, it adds another dimension to history which deepens our understanding of these historical junctures which forces women across the globe to live in silence.
\end{abstract}

Keywords-Gender, Holocaust, Partition, Violence, Women.

\section{INTRODUCTION}

Gender as a category of analysis is fundamental to understanding of Partition and Holocaust because both these events were not singular in nature. Rather, a collection of varied events which were experienced differently by people based on their caste, class but mainly due to their gender. During war and crises gender takes on primacy, women experienced Partition and Holocaust differently because they were women. Brigitte Halbmayr, in her book Sexual Violence against Jewish Women during Holocaust, discusses the notion of sexualised violence. She argues:

The term sexualised violence makes it clear that male violence against females is not about sexuality but is a show of power on the part of the perpetrator and includes many forms of violence with sexual connotations, including humiliation, intimidation, and destruction. From this we can derive that violent acts can be understood as sexualised if they are directed at the most intimate part of the person, and, as such, against the person's physical, emotional, and spiritual integrity. (30)

Somehow, honour of a man and his family came to be situated in the bodies of women of his house. Consequently, in order to soil the pride of man, the bodies of women were soiled.
Ironically, women were victims of sexual savagery not only at the hands of men of other community and religion but also by men of their own community. In the essay "Nietzsche, Genealogy, History", Foucault argues that the body manifests the stigmata of past experiences as the inscribed surface of events. He describes human body as a space where cultural hierarchies are inscribed and reinforced. He states that the initial components belonging to the domain of history such as desires, failings and errors efface each other or combine and express themselves in the body. Foucault argues that the entire mechanism of power becomes successfully operative only after it comes to be written on the bodies of individuals. The underside of Partition and Holocaust histories reveal this as the bodies of the women were literally marked with permanent ink. While, bodies of women in Indian subcontinent were marked with the religious symbol of the 'other' community; the Jew women were marked with numbers in concentration camps and systematically killed. Women in both the subcontinents were mutilated, raped, stripped naked and paraded down the streets. Hence, in times of war and conflict women and their bodies become the means through which national, racial, religious and ethnic identities are reproduced. The status accorded to them by the virtue of birth in any country be it 'first world woman' or 'third world woman' crumbles into nothingness in times of crisis and emergency 
which reveals the true state of gender binaries which exist everywhere.

\section{BODIES OF WOMEN AS SITES OF NATIONAL HONOUR AND REVENGE}

Why does a woman's body become a site of nation's honour which ultimately translates into a site for revenge? Why is defiling a woman's sexual integrity synonymous with tarnishing the pride of the family, community, nation and country? In one of the episodes of Indian television show called Satyamev Jayate, which focuses on sensitive social issues prevalent in India; Kamla Bhasin, a feminist activist, discusses the issue of rape and woman's honour. She argues: "If I am raped, people will say that she has lost her honour. How did I lose my honour? Who put my honour in my vagina?". She further says:

It is a patriarchal idea that getting raped would ruin my community's honour. I would like to ask everyone right now, why did you place your community's honour in a woman's vagina? I did not place my honour there. If anyone loses their honour when a woman is raped, it's the rapist not the woman who is raped.

These are essential questions which need to be answered in order to understand this regressive patriarchal set up which renders absolutely no agency and freedom to women over her own body. It ultimately becomes a game of power and assertion of pride over the 'other' woman's body.

Silence pervades on the other side of historical narratives of Partition and Holocaust. Women were forced to remain silent on matters of sexual savagery they were subjected to during violence and also they chose to remain silent. The idea of honour and shame has been so intricately linked up in a patriarchal set up that it gives no room for a woman to voice out her side of the story and any woman who attempts to do so is immediately shunned down even by her own family and at times especially, by her family. Any narrative which includes and recounts the events from only one side of the perspective are bound to be incomplete. In Borders and Boundaries: Women in India's Partition, Kamla Bhasin and Ritu Menon argue: "The abundance of political histories on Partition is almost equalled by the paucity of social histories of it" (6). They question the authenticity of a national historical account which conveniently drops the narrative of one half of the population that is specifically the accounts and testimonies of women. This stands true for Partition and Holocaust alike, neither of the histories could accommodate women testimonies within its historical fold.

\section{SILENCING WOMEN THROUGH HISTORICAL NARRATIVES}

Urvashi Butalia, in her book, The Other Side of Silence: Voices from the Partition of India, points out that somehow the 'history' of partition only comprised of the political developments that led up to it. She says, somehow the 'human' dimensions of this history seemed to have a 'lesser' status in it. She asks, "Why then did they live on so vividly in individual and collective memory?" Writing on Holocaust memories and testimonies James E. Young poses the question, "How can we know holocaust except through the many ways in which it is handed down to us?" Young answers his posed question by suggesting that as much as through its 'history', we know the holocaust through its literary, fictional, historical, political representations, testimonial representations for it is not only the 'facts' of any event that are important, but equally how people see those events and how they represent them. Butalia argues that the question posed by Young is well extended to Partition, for how do we know this event except through the ways in which it has been handed down to us: through fiction, testimonies, individual and collective memories, through the communalism it unleashed.

Urvashi Butalia argues that individuals and memories illuminate the underside of history. They are the ways in which we can know this event. In many senses they are the history of the event. She questions, "Is there some way in which history can make space for small, the individual voice?" Oral narratives offer a different way of looking into history, a different perspective because people locate their memories by different timeframes, than the events that mark the beginning and end of histories, their narratives flow above, below through the disciplinary narratives of history. Butalia calls these narratives "the layers of silence" of survivors and their anguish as a result of keeping their secret for decades. Agency was wrested from those women who died a gruesome death and also from those who remained to bear witness.

Jill Didur in her book Unsettling Partition: Literature, Gender, Memory demonstrates the relevance of using literary texts, especially women's narratives for understanding the underside and complexities of Partition. She argues for attentiveness to the literary qualities of women's narratives that interrogate the monolithic historical accounts of the period. She argues that the 'silences' of sectarian violence done on women should be understood as a critique of the project of patriarchal modernity which is still unable to acknowledge or understand the language of these silences. Myrna Goldenberg, in Before All Memory is Lost: Women's Voices from the Holocaust, points out the absence of female 
voices in the narrative of Holocaust and the dominance of male versions of history which are "independent of gender and considered as universal for all victims." She asserts the need to provide an agency to women who have remained silent throughout the course of history before all the memory and unsaid testimonies are lost forever. Feminist historians of both the subcontinent grapple with the difficulties of finding testimonies by women and inclusion of those testimonies in the main historical account of Partition and Holocaust, respectively.

\section{LOOKING AT PARTITION AND HOLOCAUST THROUGH TESTIMONIES OF WOMEN}

Nonica Datta in "Reframing Partition: Memory, Testimony, History" recounts that she grew up in a family deeply affected by Partition violence that chose to remain silent about the trauma that devastated their lives. She narrates a story, which her mother told her, about a relative named Nirmal, who was her mother's first cousin. Amidst the violence of Partition, Nirmal was killed in Sheikhupra (now in Pakistan) in 1947. She was only twenty-two years old and newly married. The attackers shouted the slogan of "Har Har Mahadev" and the family came out hoping that Indian Army had arrived to save them. But they turned out to be Muslims from the Baloch regiment who quickly segregated the men and women. When Nirmal's husband was about to be shot, Nirmal came in front and the bullet killed both of them instantly.

Nirmal's story reveals the complexity and ambiguity of narration. Did Nirmal actually die for her husband or did she share the similar fate which a multitude of women did during the savagery of Partition. Was her story also silenced within the historical folds of Partition? One can never tell because Nirmal is dead. Nirmail's voice will always be absent and she will continue to live in diminishing memories and soon get erased from there as well. She will not be remembered in history amongst other countless women who died and also those who survived but could never tell their stories.

Testimonies of women reveal the unsaid and undocumented traumatic holocaust experience women went through for being a woman and a Jew. Survivor Sara Moses recalls her traumatic rape by German soldiers: "I wish he had killed me instead of doing that to me. The fear inside you feel cannot be described with words- when its night, when he is armed, you do not know who he is, and he makes you take off his clothes." Throughout history wartime rape of women has been accepted as a by-product of the conflict and women among other commodities as spoils of war. Experiences and emotional trauma of the woman is not deemed worthy enough to paint the national picture to an extent that she is denied grieving even in personal space and is forced to live in denial. Sara's experience is documented as a testimony which is not given historical sanctity because historical facts and personal experiences especially those of women during war and otherwise in times of so called 'peace' are always in an opposition. Sara and countless other nameless, faceless women shared the same predicament but could not speak out.

Many testimonies of holocaust survivors which scream of sexual savagery are recorded in anonymity because women are afraid to come to the forefront and accept the trauma in a public world because of fear of being called out upon for something which is not their fault. Unfortunately, nothing has changed in this $21^{\text {st }}$ century, even after almost odd 75 years, rape victims continue to be ostracized by the community which looks for fault in the victim rather than the rapist and this stands true for first world and third world alike. The guilt and shame that survivors felt in Partition and Holocaust were made to feel, coupled with the possibility of being further marginalised and ostracized by admitting to sexual abuse, caused a culture of silence.

History is played out on a woman's body but she is not accorded the status of a martyr or even a victim; her experiences of the war are not mentioned in the domain of historical facts then how can her stories and she herself be true? Urvashi Butalia in the The Other Side of Silence titles one of the section as "History is a Woman's Body," showing how history was played out on a women's bodies during the Partition and how women became passive suffering subjects of history without being able to claim recognition of their suffering and even 'martyrdom.' The nations came into being with much fanfare and the sordid realities of communal violence which was literally inked on a woman's body was pushed into the shadows of unacknowledgement. The suffering of women at the Partition and Holocaust is rooted in national culture and gendered nationalism.

\section{CONCLUSION}

The experiences and trauma of Nirmal and Sara, though geographically apart bear some likeness. While Nirmal on one hand could not live to tell her tale even within the closed domains of her house; Sara on the other hand recorded her testimony and re-lives the past horrors each day in the present through her memory which has no space in the national history. Sara's life becomes a living 
death because the society forces her to believe so and never helps her out of the trauma. On the other side of the silence, Nirmal and Sara permeate into each other and it is difficult to tell who is who but just that they both are women who continue to live not in history but in memories of other women and will soon be erased from that as well ultimately crumbling into nothingness.

"I am also a We" is not a plea but a demand for inclusiveness in the historical narratives of Partition and Holocaust. Nationalist agendas across the globe conveniently pick and drop the women's question in favour of the larger picture of freedom and independence. It boasts of including women within the national fold but this "we" is never inclusive of the "I" of the woman. It is time to archive the speech and voices of these women within the historical account and not their silences anymore. Denial of historicity is equivalent to denial of existence which belittles the struggle of countless, faceless and voiceless women who were massacred during political upheaval of Nation carving and ethnic cleansing.

\section{REFERENCES}

[1] Banwell, S. (2015). "Rassenschande, Genocide and the Reproductive Jewish Body: Examining the Use of Rape and Sexualised Violence Against Jewish Women During Holocaust." Journal of Modern Jewish Studies, pp.1-38, 2015. Taylor and Francis, Retrieved from http://dx.doi.org/10.1080/14725886.2015.1049583.

[2] Bhasin, K., and Menon, R. (1988). Borders and Boundaries: Women in India's Partition. Rutgers University Press.

[3] Butalia, U. (1988).The Other Side of the Silence: Voices from the Partition of India. Viking by Penguin Books India (P) Ltd.

[4] Datta, N. (2017). "Reframing Partition: Memory, Testimony, History." South Asia Chronicle, pp.61-93.

[5] Didur, J. (2006).Unsettling Partition: Literature, Gender, Memory. University of Toronto Press.

[6] Foucault, M. (1982). "Nietzsche, Genealogy, History." The Archaeology of Knowledge: And the Discourse on Language. Vintage Publication, pp 145-172.

[7] Goldberg, M., (Editor) (2017). Before All Memory is Lost: Women's Voices from the Holocaust. The Azrieli Series of Holocaust Survivor Memoirs.

[8] Halbmayr, B. (2010) "Sexualised Violence Against Women During Nazi 'Racial' Persecution.” Sexual Violence against Jewish Women during Holocaust. Edited by Sonia Hedgepeth and Rachel Saidel. Brandeis University Press, pp 29-44.

[9] Subramanian, S. (2013)Women Writing Violence: The Novel and Radical Feminist Imaginaries. Sage Publications India Pvt Ltd.

[10] Waxman, Z. (2017).Women in the Holocaust: A Feminist Perspective. Oxford University Press.
[11] "When Masculinity Harms Men." (2014, November 8). [Video file].YouTube, uploaded by Satyamev Jayate. Retrieved from http://youtu.be/aOLYIzJnKT4.

[12] Young, E. J. (1994).The Texture of Memory: Holocaust Memorials and Meaning. Yale University Press. 